\title{
THE POLICIES OF YOUNG MUSLIM ASSOCIATION IN EUROPE FOR ITS INDONESIAN MUSLIMS IN DUTCH SOCIETY:
}

\section{A Re-examination}

\section{S u j a d i}

Lecturer at the Faculty of Adab, State Islamic University Sunan Kalijaga Yogyakarta.

الملخص

تنقص لدي المنظمات الإسلامبة في هو لاندا مظلة جبية ذات الصبغة الوطنية أو العالمية

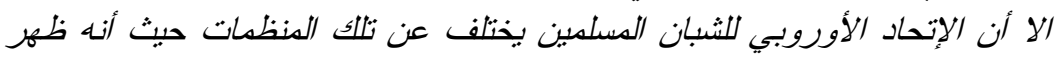

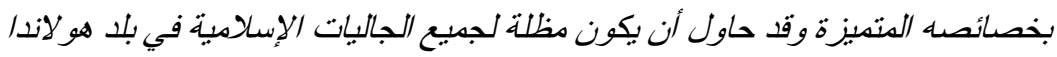

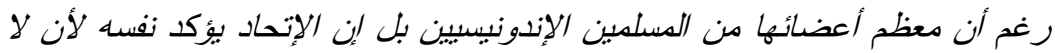

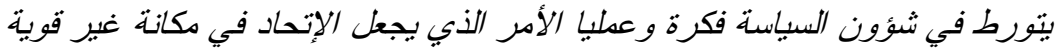

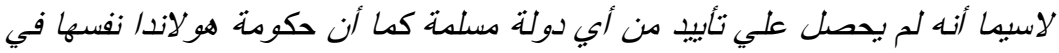

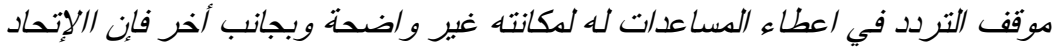

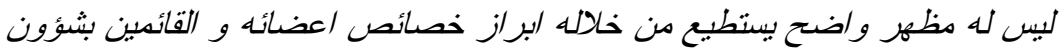

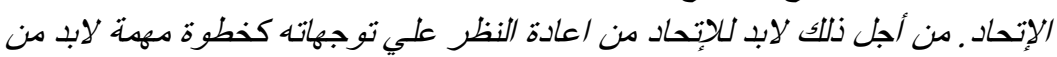

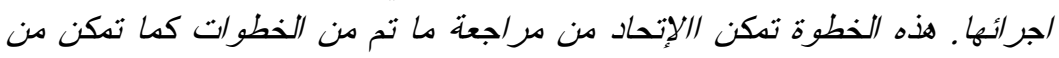

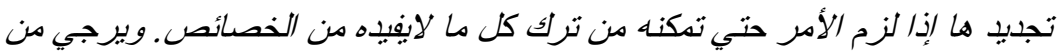

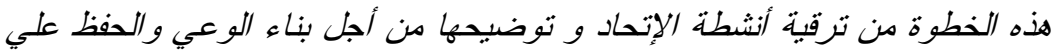

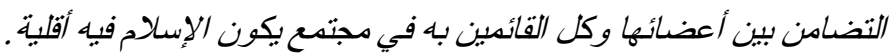

\section{Abstract}

Di tengah langkanya organisasi-organisasi Muslim baik yang bersifat nasional maupun internasional di Belanda, Persatuan Pemuda Muslim se-Eropa (PPME) merupakan pengecualian. PPME muncul dengan identitas unik, yakni mencoba berkiprah sebagai organisasi payung bagi semua etnis muslim yang ada di Belanda, walaupun mayoritas anggotanya adalah Muslim Indonesia. PPME menegaskan dirinya sebagai organisasi 
yang tidak terlibat dalam urusan politik, baik, gagasan maupun praktis. Identitas unik itu menempatkan PPME pada posisi yang tidak powerfull karena tidak ada dukungan dari satu negara Muslim. Pemerintah Belanda pun ragu memberikan subsidi karena eksistensinya tidak jelas. Selain itu, ia tidak akan punya satu wajah jelas yang harus ditampilkan sebagai identitas dari para pengurus dan anggotanya. Untuk itu, pengujian kembali (Re-examination) terhadap kebijakan-kebijakannya merupakan satu langkah yang penting untuk ditempuh, agar dapat di-review dan diperbaharui bila perlu. Melalui pengujian kembali tersebut, PPME diharapkan dapat meningkatkan dan memperjelas kiprah-kiprabnya dalam membangun kesadaran dan menjaga solidaritas para pengurus dan anggotanya sebagai Muslim minoritas.

Keywords: PPME, policy, Re-examination.

\section{A. A Muslim Minority's Peculiar Problem}

More than one third of the world's Muslims are living as minorities in non-Muslim countries, a fact which has posed challenges not only for the host countries but also for the Muslims themselves. ${ }^{1}$ The challenges could be religious, socio-cultural, economical, organizational, legal and political. Such challenges are obviously going to lead to various problems that will probably be able to solve by taking organizational solution into account. This does not signify paying no heed to others ones. Nevertheless, overcoming problems related to the existence of Muslims in non-Muslim countries seemingly calls for, for a start, the organizational ways out.

Kettani, the writer of Muslim Minorities in the World Today asserted that "it is perhaps not enough for the Muslims constituting a minority to be just 'good' Muslim, in the narrow sense of the term, to ensure the survival of the community. If those Muslims do not have the means and the desire to transmit their religions to the forthcoming generations, the community is likely to stagnate, then dissipate and ultimately disappear altogether". 2 The following affirmation is also in line with

${ }^{1}$ Muhammad Khalid Masud, "Islamic Law and Muslim Minority", in ISIM Newsletter, No. 11, (Leiden: ISIM, 2002), p. 17.

${ }^{2}$ M. Ali Kettani, Muslim Minorities in the World Today, (London: Mansel Publishing, 1986), p. 1 
the need of the means and the desire. "Until recently they [Muslims] kept a low profile. But through upward social mobility or the "braindrain' from the rest of the Muslim world, a Muslim intelligentsia has slowly emerged in Europe and is now more vocal in calling for recognition of the Muslim presence, triggering heated debates in European public opinion". ${ }^{3}$ Given that, stipulation for good and strong Muslim organizations is a must. The organization can serve as their means for keeping minority consciousness and solidarity in such a way that they will be powerful for looking after their existence in the nonMuslim countries and for being good and dynamic religious community. Through it to obtain recognition as a religious minority from both the ruling governments of non-Muslim countries and the host-societies will be more easily carried out.

Powerless Muslim organization has become, according to Kettani, the main cause for no recognition of the Muslims as a religious minority ${ }^{4}$ For this he took the existence of Muslims in France, Germany and in United Kingdom as example. In fact, if Muslim minorities in the non-Muslim land have possessed good effective and powerful organizations, they could be as centers for those Muslims' various activities, in particular, pertaining to educational, socio-cultural, economical and even political affairs. The following cases, not to mention all, have showed the demand for the inevitability.

Initially, pertained to the German Federal Republic. "The state maintains the lead in educational matters, seeking cooperation with those religious community that it acknowledges. In this legislative arrangement, religious community is only responsible for religious content". ${ }^{5}$ Subsequently, there was another case undergone by the children of Moroccan Muslim communities living in Germany, the Netherlands and France. It is informed: "When children came and new children were born, the situation changed drastically. These children were and are much more open-minded to the new societies.

${ }^{3}$ Oliver Roy, "Muslim in Europe: From Ethnic Identity to Religious Recasting" in ISIM Newsletter, No. 5, (Leiden: ISIM, 2000), p. 1.

${ }^{4}$ See Kettani, Muslim Minorities, pp. 35-43.

${ }^{5}$ Gerdien Jonker, "Connecting Muslim Knowledge to the German School System”, in ISIM Newsletter, No. 8, (Leiden: ISIM, 2001), p. 8. 
They had to enter into educational system and thus were exposed to the new languages". ${ }^{6}$ Another is about the policy document on imams and their training published by the Dutch government in February 1988. This policy raised a heated debate on responding the question: who is in control of future Imam? ${ }^{7}$ The cases undergone by Muslims living in those countries obviously require a swift and brilliant response. Such response only can be conducted if the concerned Muslims are well organized. Therefore, organization is a must.

Muslim organizations also could be exercised as means for the integration of those Muslims, as the guest societies with the hostsocieties, the societies of the home-land. Thus, their existence will be more acknowledged and accepted by both the host-societies and the ruling non-Muslim governments. Surely, this process of integration will deal with the process of 'Continuity and Change'. The instance for it is the function of an influential Turkish-Muslim organization, Süleyman cilar, in successfully finding out between the process of continuity and of change in religious ideas and structure. ${ }^{8}$

Finally, Muslims organizations hopefully can function as media for creating the image of 'Peaceful Islam' in the non-Muslim countries. This will be in line with a hope that Islam should be reformulated as a contemporary global worldview'such as the embodiment of social integration between the guest-society and the host-society.

Nevertheless, as a matter of fact, up to now Muslim's organizations that have really served, if truth be told, as either national or even international umbrella organization can not easily be found, if can not be said nothing. Probably, Young Muslem Association in Europe (PPME) is the exception.

${ }^{6}$ Jan Jaap De Ruiter, "Language and Religion: Moroccan and Turkish Communities in Europe”, in ISIM Newsletter, No. 7, (Leiden: ISIM, 1998), p. 28.

${ }^{7}$ Nico Landman, "Imam in the Netherlands: Home-Made Better than Import?", in ISIM News Letter, (Leiden: ISIM, 1999), p. 5.

${ }^{8}$ Ekkehard Rudolph, "Muslim Minorities and European Identities", in ISIM Newsletter, No. 8, (Leiden: ISIM, 2001), p. 36.

${ }^{9}$ Ibid. 


\section{B. Focus, Method, and Benefit of the Research}

Since 1971 PPME of the Netherlands has existed in the Dutch society. This is an extremely long existence, 35 years up to now. Therefore, it would be useful to re-examine the PPME's policies in organizing its Indonesian Muslims in the Netherlands. To deal with it, appropriate questions are as follows: Initially, why was the PPME found? Subsequently, what policies have been taken so that PPME could have existed and organized Indonesian Muslims in the Netherlands? For this research, socio-political approach is exercised.

The present research is aimed at re-examining the policies of PPME of the Netherlands, rather than its branches such as PPME of the Hague, Amsterdam, Rotterdam, Delft etc., in organizing Indonesian Muslims living in Dutch society so that they can keep its extremely long existence and acquire recognition from the host-ruling government, Dutch government. Do to the fact, this present research is beneficial for both Indonesian and Dutch government. For the former, by comprehending the PPME's policies in organizing Indonesian Muslims in the host-society, aids and cooperation for them can be properly conducted, and policy for them can be wisely made. Not less important, Indonesian government could take the length of its existence into account when they would like to deal with them. This is due to the fact that it has existed in the non-Muslim country more than thirty years. This signifies that Indonesian Muslims in the Netherlands are really in need of the PPME. Last but not least, the government can create some mutual cooperation when it would like to socio-politically take care of them.

Meanwhile for the Dutch government, this research will provide more accurate information and better understanding on the existence of Indonesian Muslims in the country. Through the accuracy and the better understanding, policies pertained to, particularly, integration and subsidies can be properly taken. It seems that it will be more advantageous if the government can cooperate with the PPME in socializing the government's policies to them. Further, through the cooperation the suspect of Muslims minority about policies aimed to them probably can be reduced, if cannot be eliminated. Thus, a peaceful process of their implementation can be expected. 


\section{PPME in History at Glance}

Up till now the PPME has very significantly served Indonesian Muslims residing in the Netherlands. The fact says that there exist different types of society between the host society, Dutch society and Indonesian Muslims as the guest society. The former is commonly urbanindustrial, while the latter is generally rural-agricultural. Because of the sharp difference, the latter party usually encountered obstacles when doing integration with the former party. It is even stated that: "The contemporary tendency of the Netherlands being moving towards a society in which expressions of cultural and particularly religious specificity are banned from the public sphere". ${ }^{10}$ Accordingly, the Dutch government has been in the efforts of integrating the Muslim society in such a way with the Dutch society that a peaceful life can be built. This policy has been supported by the PPME while keeping genuine social-cultural identities of its members in such a way that they remain adaptable with the cultures of the host society. Therefore, part of its most significant services is to create and keep social solidarity among its members, including those of Indonesia in origin. For strengthening the solidarity, the followings have been being conducted: regularly religious teaching, familial consultancy, social-religious activities, and doing sports together that have been agreed as its programs ${ }^{11}$. Given that, to deal with its historical background is decisive prior to the critical analysis of its policies.

In 1970s the easy access to get job in The Netherlands drew a lot of attention of Indonesian students in the Middle Eastern countries to visit the country during their vacation. ${ }^{12}$ This fact was quite different from the visit of Indonesian students to the country prior to Indonesian independence, that was to study. This was reasonable due to the fact

${ }^{10}$ Johan Meuleman, "Headscarves, Homosexuals, and Imams in the Netherlands", in ibid., p. 33

${ }^{11}$ For example in 1998, before coming back to Indonesia, the writer underwent togetherness of doing sport such as canoeing and of a religious activity such as commemoration for the Prophet Birth held in Amsterdam for all members of PPME in the Netherlands.

${ }^{12}$ Muhamad Hisyam, Young Moslem Association in Europe, (The Hague: PPME/ YMAE, 1996), p. 19 
that the wave of emigration prior to the independence derived from the upper class. They were used to have Dutch educational system. ${ }^{13}$ Thus, to study rather than to earn money was their concern.

There existed a mostly economical reason for the visit of Indonesian students from the Middle Eastern countries namely to earn money. It is true that few of them got financial aid for their daily life and expense from their family in Indonesia. However, most of them were given scholarship by the host countries. They were santri [student of pesantren, Islamic-classical educational institution]. ${ }^{14}$ And it was used for the santri to live independently. This is due to the education system of his institution taking of life style of independency and simplicity into account. Thus, the lack of finance does not really matter for him. ${ }^{15}$

Nevertheless, it is critical to state that the students from the Middle Eastern countries came to The Netherlands not only for the financial affairs. Their Islamic educational background as santri had triggered and motivated them to commit and take care of the implementation of Islamic teaching, preaching and up-grading of Muslims. At the moment, many of Indonesian Muslims in the Dutch society could not exercise their religious teaching well. This was due to the atmosphere among the Dutch society that did not support to do so. Another fact was that it was a bit difficult to find Muslims who were expert at Islamic studies ${ }^{16}$ as the party to consult. To tell the truth, these obstacles hampering the Muslims, at the moment, remain to be undergone by Indonesian Muslims in the country nowadays. ${ }^{17}$

The atmosphere went worse due to the exclusiveness of Indonesian Student Association (PPI). This organization did not make relationship with Indonesian workers in the Netherlands. Besides, it

\footnotetext{
${ }^{13}$ Harry A. Poeze, "Indonesian at Leiden University", in W.A.L. Stokhof. and N.J.G. Kaptein (ed.) Beberapa Kajian Indonesia dan Islam, (Jakarta: INIS, 1990), p. 42.

${ }^{14}$ Hisyam, Young Moslem Association, p. 19.

${ }^{15}$ Mastuhu, Dinamika Sistem Pendidikan Pesantren, (Jakarta: INIS, 1995), pp. 6264.

${ }^{16}$ Hisyam, Young Moslem Association, p. 21

${ }^{17}$ The writer, during research on Moroccan youths being Muslim amongst Dutch society in 1997, found the obstacles undergone by them. It was stated that they found the lack of facilities for religious activities, in particular, like praying rooms at the working places.
} 
did not take care of religious upgrading for Indonesian Muslims in the country but political affairs undergone by Indonesian people in their homeland. This was reasonably due the fact that they derived mostly from upper class families rather than grassroots level community. ${ }^{18}$ Its care of political affairs in the homeland resembled that of Indonesian Association (PI), that had been well-known, at the time, amongst Dutch and Indonesian politicians before the independence of Indonesia. ${ }^{19}$ It is important to note that the latter association, PI had proven itself as an association for cadre, in particular, for students who would like to struggle for Indonesian Independence. The best example for it was Mohammad Hatta, ${ }^{20}$ the late-former vice president.

All factors above had triggered Indonesian Muslim students from the Middle East to take care of their brothers in religion and in nation living in the non-Muslim country, and to think of the establishment of an organization aimed at preaching Islam. Furthermore, the ideas for its establishment had been begun to discuss among Indonesian young Muslims both living in The Netherlands and in Germany. The following is the history.

At the beginning of January 1971 the preparatory meeting was held in The Hague. The meeting was attended by thirteen people. Ten of them had been living in the Netherlands such as T. Razali, Moh. Chaeron, A. Hambali Maksum, Abdurrahman Wahid, Abdul Muiz Kaderi, Rais Mustafa, Moh. Sayuti Suhaib, Rahmat Zitter, Amir Alhajri, and Muhtar. The others had been residing in Germany. They were Abdul Wahid Kudunngga, Ali Baba and A. Dony. The result of the meeting was to further efforts for founding an organization provided for Indonesian yung Muslims.$^{21}$ This idea points out the smartness of its thinker. This is because the foundation of an association in a form or another will symbolize the existence of solidarity among the

${ }^{18}$ Hisyam, Young Moslem Association, pp. 22-23.

${ }^{19}$ Poeze, "Indonesian at Leiden University", in Stokhof and Kaptein (eds.) Beberapa Kajian, pp. 44-45.

${ }^{20}$ See Sujadi, "Mohammad Hatta's Nationalism, Islam and Recent Threat of Disintegration", in Mukaddimah, No. 10, (Yogyakarta: Kopertais of Region III/IAIN Sunan Kalijaga, 2001), pp. 40-43.

${ }^{21}$ Hisyam, Young Moslem Association, p. 23. 
community. Furthermore, this indicates the existence of Indonesian Muslim minority. It is true that there will be a Muslim who resides in a non-Muslim country because of his emigration to the country or the conversion of a non-Muslim to be a Muslim. ${ }^{22}$ However, the phenomena do not indicate yet the existence of Muslim minority because the term of minority will emerge for the reason that there have existed their awareness of being different in physic, culture, religion, language or treatment from the majority, and their solidarity for recognizing the differences by founding an organization. This clearly points out that minority is extremely identical with collectivity rather than individual.

Subsequently, in the middle of February at the same year and city was held the second meeting. This meeting recommended the forming of the commission for making composing the statutes and the rules for association. ${ }^{23}$ This recommendation was extremely required to clarify the new association's identity. Because of its existence in a non-Muslim country, the association could be set up as an organization for all Muslim ethnics or for all Muslim organizations of single ethnic. ${ }^{24}$ Thus, what have been categorized, pertained to the types of Muslim's organizations, could come into existence. ${ }^{25}$

Lastly, on April 11 till 12, 1971 was held the third meeting at the same place, and was attended by twenty one people. The meeting succeeded in coming to an agreement that the name for the new young Muslims organization in the Netherlands was Persatuan Pemuda Muslim se-Eropa, (in Dutch, Vereniging van Islamitische Jongeren in Europa and in English, Young Muslem Association in Europe, PPME). This new organization also succeed in electing Abdul Wahid Kadungga as the

${ }^{22}$ Kettani, Muslim Minorities, p. 2.

${ }^{23}$ Hisyam, Young Moslem Association, p. 24.

${ }^{24}$ Kettani, Muslim Minorities, p. 6.

${ }^{25}$ There exist four types of Muslim organization such as the organization under one of Muslim countries of origin; the organization depending on Muslim countries' government; the organization affiliated to international religious movements of a specific confessional orientation; or the grassroots-level organization. Read: W.A.R. Shadid and P.S. van Konigsveld, Religious Freedom and the Position of Islam in Western Europe, (The Netherlands: Kok Pharos, 1995), p. 43. 
first chairman of it. ${ }^{26}$ The principle of shürä (mutual consultation) that should be exercised in order that the objective of the new association to establishing a viable Muslim community, like Kettani addressed, ${ }^{27}$ could be clearly seen from the election. Familial atmosphere had covered the election. The principle of syüra had been implemented in the framework of Indonesian fourth principle of Pancasila, that was the deliberation for consensus. There existed no coercion and elimination of a person toward another in the process of electing the chairman. The best example for it was that Abdurrahman Wahid was actually expected to lead the association by those attending the meeting. However, the expected was reluctant to occupy the position due to his planning of coming back to Indonesia rather than of living in the nonMuslim country. Further, because of his objection Kadungga was finally posed, through their consensus, for the position. ${ }^{28}$ Thus, what is expected, once more, by Kettani, that is that change should be on the basis of consensus had been taken. ${ }^{29}$

\section{PPME's Policies to Be Re-examined}

Since 1971 PPME has made strategic policies in positioning itself, its boards and its members. The policies can be principally categorized into internal and external. For the former form of policy, initially it has been stated that its basis of struggle is Islam, and it does not rely on a certain ethnicity, for example, Indonesian Nationalism. This policy was made in order that it could move freely, and was not restricted, due to its affiliation, to a certain citizenship. ${ }^{30}$ This step will only be beneficial if the PPME is set as a national umbrella for Muslim organizations in the Netherlands. This step is probably similar to what

${ }^{26}$ Those who signed the establishment of the association were as follows: M.Suyuthi Suhaib, Abdul Wahid Kudungga, Imam, Ozir M. Isa, Rusli Bena, A. Hambali Maksum, Ujang HS., Azmihardi, T. Razali, Husni Basuni, Ali Khalik, S. Abidin, I.Idram, Hisyam, M. Rais Mustofa, A. Muiz, Suwardi, Abdurrahman Wahid, Moh. Syukur, Machfud Muchtar, Moh. Amir, and Ade Baharuddin. See: Hisyam, Young Moslem Association, pp. 24-25.

${ }^{27}$ Kettani, Muslim Minorities, pp. 6-7.

${ }^{28}$ Hisyam, Young Moslem Association, p. 25.

${ }^{29}$ Kettani, Muslim Minorities, p. 8.

${ }^{30}$ Hisyam, Young Moslem Association, p. 25 
have been taken by Arab nationals of Muslim in Switzerland. It is stated that: "Arab nationals in Switzerland affirm an engaged Muslim identity by a rejection of national and cultural ethnicities". ${ }^{31}$ Otherwise, this organization will be vulnerable. This is due, for a start, to the fact that the "pristine cultures divide the Muslim community in Europe". ${ }^{32}$ Furthermore, this PPME has no ethnic identity because it does not attach itself to a certain nationalism. In consequence, it has no structural channel to a certain Muslim government of Mmuslim countries, for example Indonesian government. Accordingly, it belongs to all Muslims who wish become its member. The only identity it possess is Muslim ethnic. In fact, the identity is considered to be a quasi-ethnic group. ${ }^{33}$ This implies that possessing the identity of Muslim or Islamic Ethnic is unhelpful for obtaining significant aids from a certain Muslim government. This is because PPME is not a part both of "those organizations which mainly resort under the authority of the government of the countries of origin, and of organizations depending on the governments of the various Muslim countries" ${ }^{34}$

Subsequently, having run two years PPME was legally recognized by the Dutch government as a Muslims' organization existing in the Netherlands on the basis of the Dutch Queen Decision of No. 58, May 4, 1974. PPME was, according to the decision, recognized as a vereiniging, association rather than stichting, foundation. ${ }^{35}$ This policy has to, in fact, be taken. Through this legalization PPME will be secure from political discrimination, in particular, related to subsidies provided by the Dutch government. Because of it PPME deserves the chance for the subsidies. This is seemingly in line with the policy of the Dutch government, that has separated church from the state. However, the fact has been vice versa. It is affirmed that: "The separation of church and state is, in fact, used as legitimation to prevent subsidizing Islamic

\footnotetext{
${ }^{31}$ Patrick Haenni, "Divergent Trajectories Islam and Ethnicity in Switzerland", in ISIM Newsletter, No. 6, (Leiden: ISIM, 2000), p. 31.

${ }^{32}$ Olivier Roy, "Muslim in Europe: From Ethnic Identity to Religious Recasting" in ISIM Newsletter, No. 5, (Leiden: ISIM, 2000), p. 1.

${ }^{33}$ This term refers to that of Olivier Roy; Ibid.

${ }^{34}$ Shadid and Konigsveld, Religious, p. 43

${ }^{35}$ Hisyam, Young Moslem Association, p. 31.
} 
prayers facilities and school". ${ }^{36}$ This is absolutely opposite to "the principle of non-discrimination, based on religion, etc. (Art. 1) which entails, among others, the equal treatment of religious groups. If the state, for reasons of public interest, decides to supports certain religious groups in building up or maintaining some of their infrastructural provisions.... ${ }^{37}$

It is true that PPME as a vereniging find a bit complicated in relation to acquiring subsidy from the Dutch government. It must take account of existence of its branches spreading over the country, of multi-ethnicity of its members, and of the commitment of its boards. Nevertheless, as a vereniging it is easier for it to establish a foundation, to move freely, and to be democratic due to its nature and its procedure in making decision, that is to have to pass a general deliberation. ${ }^{38}$ However, the legalization is a must because PPME does not belong to a certain ethnic and is not affiliated with a certain government. Thus, the policy is in line with the reason for establishing its existence and acquiring legal certainty in its activities. ${ }^{39}$

Thirdly, PPME has addressed that it was founded for Islamic enlightenment and education rather than political movement or affairs. ${ }^{40}$ It has also been affirmed that its involvement in political practice will only bring about frictions among its boards and members. This will most likely be proper, if PPME has provided a political channel outside its structure. Otherwise, the political aspiration of its boards and members cannot be expressed because of no political channels. This is psychologically not health. The political channel will serve as the media for both political accommodation and inventory of political ideas in such a way that the political aspiration of PPME's members and boards remains recognizable by other related parties. This is not as hard as that of Omar Khalidi suggesting "Muslim minorities [have to] work as closely as possible with national and mainstream political parties to

\footnotetext{
${ }^{36}$ Sadik Harchaoui, "Church and State in Multicultural Society", in ISIM Newsletter, No. 11, (Leiden: ISIM, 2002), p. 12.

${ }^{37}$ Shadid and Konigsveld, Religious, pp. 18-19.

${ }^{38}$ Hisyam, Young Moslem Association, p. 31.

${ }^{39}$ Ibid.

${ }^{40}$ Ibid., pp. 34-39
} 
achieve physical security". ${ }^{41}$ This suggestion seems to be good, however it will be impossible to be applied by Muslim minorities in the Netherlands due to the fact that "there are no Islamic parties at national or local level with political power to favour Islam over other ideologies," ${ }^{42}$ and "there is no unified national Islamic organization". ${ }^{43}$ Nevertheless, the absence of the two media should strengthen the commitment of PPME's boards to think of creating political channels in such a way that its member won't blind with political issues and matters pertained either to the countries of origin of its members or to the country in which they have been residing.

At last, PPME is set as the media for the forming of cadres regardless of any sect or school of organizational background possessed by a board or member during his or her life in Indonesia. Examples for the forms of cadres are such as the training on organization, particularly for its boards and its successors, monthly Islamic studies in each branch of PPME, flits school (like a short course held in vacation days), etc. ${ }^{44}$ This neutrality is necessary to keep in order to prevent, particularly, its boards from discriminating its members or those whose would like to follow PPME's activities or programs. In addition, the crucial for PPME is actually to create the image of Peaceful "Euro-Islam" rather than Radical "Ghetto-Islam". ${ }^{45}$ The former term "sees itself as a permanent presence in the space of Europe", while the latter "mirrors the continued rejection of Islam by white/Christian majority cultures". ${ }^{46}$

The forming of its cadres holds true for creating the Peaceful Euro-Islam. It is, further, expected that its successors, the cadres, would like to lead the members of PPME to a spot, in which integration and

${ }^{41}$ Omar Khalidi, "Muslim Minorities: Theory and Experience of Muslim Interaction in Non-Muslim Societies", in Syed Z. Abedin (ed.), Journal Institute of Muslim Minority Affairs, Vol. X, (UK: Institute of Muslim Minority Affairs, 1989), p. 433.

${ }^{42}$ Sadik Harchaoui, "Church and State in Multicultural Society", in ISIM Nensletter, No. 11, (Leiden: ISIM, 2002), p. 12.

${ }^{43}$ Ibid.

${ }^{44}$ See:Hisyam, Young Moslem Association, pp. 48-50.

${ }^{45}$ These terms have been posed by Mark Levine in his writing: "Muslim Responses to Globalization”, in ISIM Newsletter, No. 10, (Leiden: ISIM, 2002), p. 1.

${ }^{46}$ Ibid. 
peaceful relation with the host-society rather than isolation from it and radicalism are put forward. Furthermore, the effort for the forming of cadres is not satisfactory yet when compared to the following suggestion: "The great task [for Muslim minority] therefore is to redouble existing efforts to create a favorable atmosphere for Muslim to win hearts and minds at the school desk, at the news-stands and on the TV screens". ${ }^{47}$

For the latter form of policy, initially, PPME has arisen both national and international oriented. It has developed cooperation with other Muslim organizations existing in the Netherlands and all over the world including those in Indonesia. This policy is made for the following reasons. To begin with, it is necessary for PPME to acquire the recognition of Muslim countries all over the world. Besides, the policy has been aimed at improving its participation and involvement in social-religious affairs all over the world. Last but not least, it is made for creating networking with countries concerned. ${ }^{48}$

To conduct the policy PPME has taken following strategies:

For a start, the communication has been built through the exchange of information with other Muslim organizations. It is used for the PPME to exchange magazine, bulletin or journal with them. Nevertheless, this exchange unfortunately does not go to cooperation. Secondly, the networking has been conducted through a joint activity, together with another Muslim organization. The example for it is that PPME and Stichting Der Islamitische Gemeenten in Suriname (SIS) cooperated in inviting a preacher for their social-religious activity. Lastly, another form of networking is participatory. This communication is created with the involvement of PPME in establsihing a Muslim organization by placing its person to be a member or its representative. This has worked well. The fact can be seen from the establishment of Federatie Organisaties Muslim Nederland, Islamitische Informatie Centrum, Nederladse Muslim Raad, Nederlands Islamitische Parlemen, etc. Meanwhile for international level, the PPME has become a member of World Assembly of Muslim Youth (WAMY). Besides, it has built cooperation with Mu'tamaru'l-'̄Alamil'-Islamy

${ }^{47}$ Omar Khalidi, "Muslim Minorities: Theory and Experience of Muslim Interaction in Non-Muslim Societies", in Syed Z. Abedin (ed.), Journal Institute of Muslim Minority Affairs, Vol. X, (UK: Institute of Muslim Minority Affairs, 1989), p. 433.

${ }^{48}$ Hisyam, Young Moslem Association, p. 42. 
Pakistan, World Assembly of Muslim Youth-Riyadh, Islamic Centre of USA, Canada, Turkey, etc. ${ }^{49}$

The policy above could be excellent. As a matter of fact, no unified national Muslim organization can be found in the Netherlands, although "various initiatives have resulted in the foundation of national organizations. Many of these aim at bringing together the local mosqueorganizations of the same ethnic groups. Others have an interethnic goal and focus on specific sections of the Muslim population". 50 Through the national and international vision, PPME could be the sole association which aims at uniting, at least, Muslim people in the country. Nevertheless, this does not signify easy work. To be an umbrella organization will frequently face political and ideological state of affairs. ${ }^{51}$ Therefore, actually the policy hold only true for an umbrella organization that does not get rid itself of political or ideological affairs. This means improper for the PPME due to its neutral position from the affairs. In addition, its position has been weakened with its neutrality from affiliation with a certain government of Muslim countries or various Muslim governments. ${ }^{52}$

The second policy is to always attempt to keep communication with Indonesian embassy although it has no structural-juridical connection with the embassy. ${ }^{53}$ This policy made was for the following reasons. To begin with, one of the functions of the embassy is to look after Indonesian citizens in the Netherlands. Subsequently, the embassy has to serves their citizenship affairs. Accordingly, PPME must keep the communication. ${ }^{54}$

To some extent, the policy made above seems to be helpful for its Indonesian members in origin. However, if the PPME remain placing itself as a Muslim organization umbrella for all Muslim ethnics, it should made the same policy for its other members deriving form other ethnics or nations in origin such as Surinam, Malaysia, Philippines, the

\footnotetext{
${ }^{49}$ Ibid., pp. 42-43.

${ }^{50}$ Shadid and Konigsveld, Religious, p. 42.

${ }^{51}$ Ibid.

${ }^{52}$ Ibid., pp. 45-46.

${ }^{53}$ Hisyam, Young Moslem Association, p. 45.

${ }^{54}$ Ibid., p. 47.
} 
Sujadi

Netherlands, etc., regardless of Indonesian members as the majority. This aims at preventing it from treating them discriminatively. Through this justice, for a start, political gaps amongst all its member can be hopefully lessened, if not be able to be eliminated. Thus, Muslim world recognition for its status as the umbrella can be kept. ${ }^{55}$ Furthermore, the justice will not place the majority as the superior, the always correct, and the more farsighted party. ${ }^{56}$

Nevertheless, the policy of keeping communication with Indonesian embassy remain facing a dilemma. When PPME creates harmonious relationship, it is considered a lackey of the embassy. Otherwise, it is regarded anti-Indonesia. However, as matter of fact, the decision of Dutch Queen no. 58 of May 4, 1974, has addressed that it has been an independent social organization. Thus, it possesses no structural-juridical relation with the embassy. ${ }^{57}$

In fact, due to the functions of the embassy such as developing Indonesian society and serving Indonesian people for their citizenship affairs, the PPME has created familial relationship like a matured child (PPME), and a parent (the embassy). Information coming from the embassy has been frequently published in the bulletin belonging to the PPME, al-Ittibäd. The embassy and the PPME have sit together in deciding the day of Ramadan and the day of $\bar{T} d$ al-Fitr. Facilities such as meeting room or financial aid has been often provided by the embassy to it. Lastly, legal proof such as for marriage certificate has been produced by it even though the marriage itself is conducted by the PPME. ${ }^{58}$

It is crucial to more closely deal with the policy that the PPME has been keeping no structural-juridical relation with Indonesian. The reason for it seems to be easily found in its statutes stating that it does not only belong to a certain ethnicity or nation, like Indonesian. ${ }^{59}$

\footnotetext{
${ }^{55}$ Sadid and Konigsveld, Religious, p. 46.

${ }^{56}$ Fred. H. Willhoite, Power and Government, (California: Brooks/Cole Publishing Company, 1988), p. 121.

${ }^{57}$ Hisyam, Young Moslem Association, p. 48.

${ }^{58}$ All information above are obtained from the visit of the writer (in 1997-1998) to the PPME's mosque in the Hague when its social-religious activities were conducted.

${ }^{59}$ Hisyam, Young Moslem Association, p. 47.
} 
This policy will be helpful for preventing from its independency on a government of a certain ethnic or nation. Subsequently, hopefully this association is going to be powerful and well organized. However, this does not mean getting rid itself of the relation with the embassy. It should be even kept while creating communication or relation with other embassies related to various ethnics of its members. All those will be only proper in the frame of PPME as the umbrella organization. What the association must be concerned is not to be dependent on the non-Muslim government, the Dutch government. For this, it has been be warned that the less Muslims are dependent on the official machinery of the state [ the state in which Muslim minority have been residing], the less likely the ability of non-Muslim state to meddle in the community matters. ${ }^{60}$

\section{E. Concluding Remarks}

Having discussed the policies of PPME of the Netherlands, we come to conclusion. To begin with, the PPME came into existence in a non-Muslim country, the Netherlands due to the high care of, and strongly curiosity of Indonesian Muslim students from the Middle Eastern countries toward religious and social-cultural problems encountered by Indonesian Muslims residing in the non-Muslim country. This occurred mostly because of their extremely high- religious commitment as santri. The association, furthermore, has been taking care of social-religious matters of both Indonesian Muslim community and its members from other ethnics in origin, in spite of the history of its establishment directed to the social-religious affairs of the Indonesian religious community.

Subsequently, the PPME should possess a strong identity. This is crucial for its status either as an association which is under the authority of a certain government of a country in origin, an association which relies on the governments of various Muslim countries, an association which is affiliated with internationally specific religious confessional orientation, a grassroot-level association, or other types. ${ }^{61}$

${ }^{60}$ Omar Khalidi, "Muslim Minorities: Theory and Experience of Muslim Interaction in Non-Muslim Societies", in Syed Z. Abedin (ed.), Journal Institute, p. 433.

${ }^{61}$ Shadid and Konigsveld, Religious, p. 43. 
Sujadi

In addition, national and international policies should be in line with its statutes and rules for its association. Moreover, political aspirations and affairs off its members should be accommodated in such a way that they remain be able to serve as the trigger for the progress of its social-religious activities., Lastly, in spite of its doubtful identities, the PPME could have existed amongst the Dutch society for more than thirty years because of its strong efforts of its boards leading it to be put as "Euro-Islam" rather than "Ghetto-Islam". 


\section{BIBLIOGRAPHY}

Abedin, Syed Z. (ed.), Journal Institute of Muslim Minority Affairs, Vol.

X, (UK: Institute of Muslim Minority Affairs, 1989).

Hisyam, Muhamad, Young Moslem Association in Europe, The Hague:

PPME/YMAE, 1996.

ISIM Newsletter, No. 1, Leiden: ISIM, 1998.

ISIM Newsletter, No. 7, Leiden: ISIM, 1998.

ISIM News Letter, No. 22, Leiden: ISIM, 1999.

ISIM News Letter, No. 3, Leiden: ISIM, 1999.

ISIM News Letter, No. 4, Leiden: ISIM, 1999.

ISIM Newsletter, No. 5, Leiden: ISIM, 2000.

ISIM Newsletter, No. 6, Leiden: ISIM, 2000.

ISIM Newsletter, No. 8, Leiden: ISIM, 2001.

ISIM Newsletter, No. 8, Leiden: ISIM, 2001.

ISIM Newsletter, No. 10, Leiden: ISIM, 2002.

ISIM Newsletter, No. 11, Leiden: ISIM, 2002.

Karim, Khalil Abdul, Al-Islām bayna al-Dawlat al-Diniyya wa'-Dawlat al-Madaniyya, Cairo: Dâr Misr al-Mabrûsa, 2004.

Kettani, M. Ali, Muslim Minorities in the World Today, London: Mansel Publishing, 1986.

Lewis, Bernard, The Crisis of Islam, $1^{\text {st }}$ ed., Surabaya: Jawa Pos, 2004.

Mastuhu, Dinamika Sistem Pendidikan Pesantren, Jakarta: INIS, 1995.

Mukaddimah, No. 10, Yogyakarta: Kopertais of Region III/IAIN Sunan Kalijaga, 2001.

Shadid, W.A.R and Konigsveld, P.S. van, Religious Freedom and the Position of Islam in Western Europe, The Netherlands: Kok Pharos, 1995.

Stokhof, W.A.L., and Kaptein, N.J.G. (ed.) Beberapa Kajian Indonesia dan Islam, Jakarta: INIS, 1990.

Willhoite, Fred. H., Power and Government, California: Brooks/Cole Publishing Company, 1988. 